\title{
Sociological Study of the Role of Information Technology in Creating Social Networks
}

\author{
Faranak Seyyedi
}

\begin{abstract}
The purpose of this study was analytical study, effect of the most important present event, which is information technology on formation of new type of human communication, and design a model on the relation between persons and type of society. This paper, relying on the literature of sociology in relation to the society and technology. The theoretical frame work of this study is borrowed from Castells's theory. Using existing documents and comments sociologists in this field was the study guide. The results show that this new communication channels, provides a link that gives shape to life, and accept forms from life. With accelerating speed of information technology, there is reshaping, foundations of society. Culture is formed by the symbols, which are formed due to electronics.

The development of informal communication and participation in social networks, through the formation of peer groups and networks of community-based with the aim to strengthen social skills. Because people fellowship in the social network and informal communication with values and norms of other society and virtual culture. Also, the economy, does not depend to money, such as past, but it is dependent on information, and social capital, is related to rate of this communication, in society. Therefore, understanding the community, is not possible, without electronic instruments.
\end{abstract}

Index Terms - Community-based networks, information technology, network, social networks, social capital.

\section{INTRODUCTION}

According to Toffler, the information age began in 1955, and technology has a major role in the development of the information society. The use of technology is lead to, saves time, increases in human effort, less travel, the spread of cultures.

Technology in nature, is one of products of society and power relations in society. It is a phenomenon that is shaped by social forces, and helping to shape the same force. Information technology is lead to awareness, prosperity, freedom from fanaticism oriented, a good opportunity to understand, good opportunity of living. But it has its challenges. Manipulated information, will affect everything. Development of technological tools, provide field for production of new subcultures. Understanding of society is not possible without its technological tools.

The poster says:

Expanding information technology, has effects on the deep, lifestyle, and our thinking, about ourselves and our environment around. Because this expansion is modified,

Manuscript received March 28, 2012. ; revised April 30, 2012.

Faranak Seyyedi is with the Faculty Member of Islamic Azad university Arak Branch (e-mail: F-Saidy@iau-arak.Ac.ir). our social network. [1]

World has become, quickly, into an information society. A society that in it wisdom and access, and useful use from knowledge is a central and decisive role. Society without culture of information, can not reach a high level economic and technological. The study of, its effects on various aspects of life is, from the most important day's discussions.

\section{CyberspaCe}

Cyberspace is an interactive space which people are not only recipients, such as radio and television.

They are also both sender and receiver and also the people who live in cyberspace deliver and receive services in this area and find the virtual identity. There is virtual identity with the other terms in scientific texts and articles, such as anonymity, ananymans, online mask or masquerade. The most important trait of the virtual identity is not recognized it. In this space, people can be introduced artificially and Individuals can have an identity other than the original identity. Everyone is responsible for his behavior and speech in the real world, but freedom of expression is higher in the virtual identity.

It is the responsibility of both speech and thought and the person may be unhappy with some of his real identity, such as education, family situation, gender or social circumstances and to console himself with dummy identity. Consolation that, he may change all or part of their real identity. It may show itself differently for mischievous, deception, manipulated by financial and sexual abuse.

Nowadays people are buying and selling through the internet .Training are also in the virtual world. Jobs are also looking to through the internet and spend their leisure time on the internet. People can check their accounts through the internet as well as pay. As the statistics show that the process of" Mediatisation " and " Domestification " can be describe the main part of the leisure of young living in modern societies. Today's youth spend more leisure time in private and into increasingly rely on new media for entertainment. Many thinkers believe that the critical stage of adolescence is identity formation, because at this young age, they realize their cognitive and social maturity.

Quoted by UNAMA: Youth have the power and capacity in the evaluation of abstract concepts such as nationality, race and ethnicity. [2]

"In recent decades, social structures like class (the production) which finds meaning in the context of identity is lost". [3] 


\section{NETWORK}

Network is composed from set of connection points, or nodes interconnected. Connection points, depending on the type of network, for example, in political network, dominant Union of Europe, connection points, are National Council of Ministers and senior European officials. Or in the global financial network, connection points are stock markets, and their ancillary service centers. [4]

\section{SOCIAL NETWORK}

Social networks is a social structure, which is composed of individuals or groups. Their relationship is as friendship, kinship, supportive, transaction, emotional, cognitive. This structure, perhaps, have centralized management, or without management. Each network is composed of a number of connection points or nodes (similar to nerve synapses) that the information flows among them. And control is exercised through them. Social networks are open structures, which can spread without any restriction, and be receptive, new nodes, as long as they have communication ability. In other words, as long as they have, codes common communication (eg , values, common goals).[5]

\section{NETWORK SIZE}

The network size, complex individuals, which are interconnected in a network. They know each other, and are linked together, which can include relatives, friends, neighbors and colleagues. [6]

\section{KINDS OF SOCIAL NETWORKS}

1) Emotional support network .This network is included, who have together, a very near relationship. The purpose of this network, is emotional protection, individuals in group.

2) Social support network. This network is larger than network of emotional protection. Emotional needs, not present in this network. This network of individuals, those who were called for different affairs. This affairs are variable, and maybe affairs will be very important or less important.

3) Unified networks: This network will included, individual who recognizes them. Many people do not have specific task, except, as information carrier. Among them, can be mentioned, the network who can provide information about, employment opportunities.

4) Informal social communication networks: Face to face relationships between a few people ho know each other, and through kinship ties, friendship, and neighbors are interdependent. Base on trust and cooperative relations between members of network that shared social identity of their own, think similar, they interact with each other. These networks, based on not written law, and based on informal norms and values, are managed and controlled.

5) Formal social communication networks: Face to face relations between people based on rules and laws are defined, Relations, usually is president and subordinate, are only within rules, together with associated.

\section{COMMUNITY - BASED NETWORKS}

It is a kind of social network, Which today are created with the goal community empowerment. Through it individual or community, with participation and utilization of existing resources and capacities, are possible, monitoring, evaluation and assessment measures. Which eventually, leads to change, based on insights and own capacity, or community .Today, this network used in combat, some of the social pathology.

\section{SHAPE OF SOCIAL NETWORKS}

The shape of a social network helps determine a network's usefulness to its individuals. Smaller, tighter networks can be less useful to their members than networks with lots of loose connections to individuals outside the main network. More open networks, with many weak ties and social connections, are more likely to introduce new ideas and opportunities to their members than closed networks with many redundant ties. In other words, a group of friends who only do things with each other already share the same knowledge and opportunities. A group of individuals with connections to other social worlds is likely to have access to a wider range of information. It is better for individual success to have connections to a variety of networks rather than many connections within a single network. Similarly, individuals can exercise influence or act as brokers within their social networks by bridging two networks that are not directly linked (called filling structural holes).[7]

Social capital in social networks, depends on the number of connections. As number of additional connections, that is greater participation, and ultimately more social capital.

\section{Approach to NeTWORK ANALYSIS}

Net per person, based on the links and relationship formed. Links the individual with their network members, including relatives, friends and colleagues and peers, it makes up in his daily life, to a considerable extent, a variety of support, it provides that members of the network, using to. Turns of the network, the resourced are, where necessary, can refer to them. To receive social assistance from the network. Causing the people in dealing with problems, which have the capacity to fight. So synonymous with some of the social network of social support, considered, and that personal network, most people living in crisis support and eve claim that recipients of personal support, physically and mentally, that those who lack this support, a healthy trend. In the discussion of the characteristics of personal networks.[6]

\section{Theoretical Aspects}

The first, the participants discussed social networks are scholars such as Emile Durkheim and Ferdinand Tonnies. Durkheim in the study of traditional communities, it knows based on mechanical solidarity, which is derived from collective consciousness. In industrial societies, is organic 
solidarity, based on human differences, and their relationships in system of social division of labor. Tonnies also, are divided, their society, according to type of communication, the two gemeinschaft( personal Relation ) and gesellschaft (instrumental Relation).

Simmel essays pointed to the nature of network size on interaction and to the likelihood of interaction in ramified, loosely-knit networks rather than groups (Simmel, 1908/1971).

In 1940, A.R. Radcliffe-Brown's presidential address to British anthropologists urged the systematic study of networks. [8]

Castells believed:

The information revolution, which began from Silicon Valley, in California in 1970s, with unprecedented speed, created change in the infosphere of natural and cultural infosphere, and, man's spiritual infosphere . Information technology, and communication provided, possibility of the network society, which people get, in the form of fresh, new identities, and offers new definitions from human.[2]

Studies have shown that social networks have an important role in social movements (Line, 1999), employment [9] and dynamics of fashion, temporary social interests [10], forming to features individuals (Lee, 2004), the rate of disease [11].

\section{CONCLUSION}

To better understand the world in which we live, it is necessary, review changes that occur. Without doubt, the creation of, social networks have been, aspect explain of activities of twenty-first century. Social networks are shown, importance of flow of information. Social networks, can be considered social impact of technology. There is exchange of thoughts, through social networks. Communications at higher levels will become the global social network. The emotional support that previously was done, through person, now, that is done, in the form of social network. Society without culture of information, can not reach into high level of economy and technology. The process of change in social networks, goes beyond from social relations and production. This process affects on culture, and power. Cultural effects, separate from local environment and geography, and ultimately, they are transmitted, via electronic communication networks.

Individuals, in this networks by using communication skills, and analytical ability, which can be near their culture, and ultimately, the creation of global culture. Thus, Individuals become global citizens.

Thus, in traditional societies, due to lack of technology tools, was tendency to oral conversation and in industrial society, the type of communication was by writing and speaking. But in information society, based on information technology, the type of communication is based on, virtual interaction and social networks. Economy is not based on capital, but it is based on the information. Power tools, in traditional societies, was land, and industrial communities, was capital, but in information community, it is access to information via technology.

TABLE I: THE RELATIONSHIP BETWEEN THE TYPE OF SOCIETY AND TYPE OF HUMAN RELATIONS

\begin{tabular}{|l|l|l|l|l|l|}
\hline $\begin{array}{l}\text { Type } \\
\text { of } \\
\text { socie } \\
\text { ty }\end{array}$ & $\begin{array}{l}\text { Type of } \\
\text { relation } \\
\text { ship }\end{array}$ & $\begin{array}{l}\text { Relatio } \\
\text { nship } \\
\text { level }\end{array}$ & $\begin{array}{l}\text { Range } \\
\text { of } \\
\text { commu } \\
\text { nication }\end{array}$ & $\begin{array}{l}\text { Dominan } \\
\mathrm{t} \\
\text { commun } \\
\text { ication } \\
\text { tools }\end{array}$ & $\begin{array}{l}\text { Dominant } \\
\text { power tools }\end{array}$ \\
\hline $\begin{array}{l}\text { Tradi } \\
\text { tiona } \\
\text { l }\end{array}$ & $\begin{array}{l}\text { Face to } \\
\text { Face }\end{array}$ & Micro & $\begin{array}{l}\text { Friends } \\
\text {,elative } \\
\text { sela }\end{array}$ & Speaking & Ground \\
\hline $\begin{array}{l}\text { Indu } \\
\text { strial }\end{array}$ & $\begin{array}{l}\text { Writing } \\
\text { ang } \\
\text { Face to } \\
\text { Face }\end{array}$ & Middle & $\begin{array}{l}\text { Friends } \\
\text {,elative } \\
\text { sang } \\
\text { Nationa } \\
1\end{array}$ & $\begin{array}{l}\text { Writinga } \\
\text { Speakin } \\
\mathrm{g}\end{array}$ & Capital \\
\hline $\begin{array}{l}\text { Infor } \\
\text { mati } \\
\text { on }\end{array}$ & Internet & Macro & $\begin{array}{l}\text { Univers } \\
\text { al }\end{array}$ & $\begin{array}{l}\text { Chat } \\
\text { online }\end{array}$ & Information \\
\hline
\end{tabular}

\section{REFERENCES}

[1] M. Poster. "The Mode of Information and Postmodernity." In Crowley and Mitchell. 1994, pp. 173-192.

[2] A. J. Umana-Taylor, "A Longitudinal Examination of Latino Ado lescents Ethnic Identity, Coping With Discrimination, AND Self -Esteem," Journal of Adolesence, 2008, vol. 28, no. 1, pp. 16-50.

[3] H. Chavshyan, "life style and social identity: consumption and taste choices as social differentiation and the similarity in the late modern period," PhD thesis, Faculty of Social Sciences of Tehran University, 1381.

[4] M. Castells. "Information Age: Economy, Society and Culture (strength of identity)." Translated Alyqlyan Ahad, A. Khakbaz, H. Chavshyan, Tehran, the new plan, 1385, P. 544

[5] M. Castells. "The Information City: Information Technology," Economic Restructuring and the Urban - Regional Process. Oxford: Blackwell, 1989.

[6] Wellman,barry (1992) Which type of ties and network provide what Kinds of social abort.

[7] J. Scott. Social Network Analysis. London: Sage, 1991

[8] A. R. R. Brown. "On Social Structure." Journal of the Royal Anthropological Institute, vol. 70, pp. 1-12, 1940.

[9] M. Granovetter. Getting a Job: A Study in Contacts and Careers. Second edition, U niversity of Chicago Press, 1995.

[10] J. D. Watts, P. S. Dodds, and M. E. J. Newman, "Identity and Search in Social Networks.” Science. 2002, 296: 1035-1302.

[11] Morris and M. Kretzchmar, Concurrent Partnerships and Transmission Dynamics in Networks. Social Networks. 1995, vol. 17, pp. 299-318.

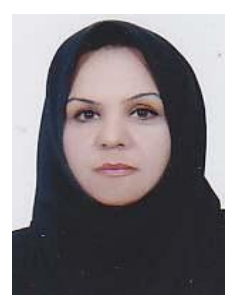

First a author. Date of Birth: 20th August 1968. Educational Background: 1997 - 1999 MA in Sociology, Islamic Azad University of Arak, Arak Iran. 1986- 1991 BA in Midwifery, Shiraz University, Shiraz- Iran. 2008 - Present PHD Student in Sociology, Islamic Azad University Research and Sciences Branch of Tehran , Tehran-Iran. Faranak Seyyedi is a faculty member of Islamic Azad University of Arak, Arak - Iran. She is PHD student in Islamic Azad University, Tehran, Iran. She is a specialist in social science and sociology, also she is editor of an international, peer reviewed, open access journal "European Scientific Journal". Now, she is member of the research committee. She has 2 book and she has also published over 10 articles in scholarly journals. Seyydei has two paper accepted at international conferences of ICIMT 2011 and ICICN 2012. She has been the best researcher in 2001 award winner. She has had several lectures, in Iran. 